\title{
Evaluation of antibacterial activities of euphorbia heterophylla
}

\author{
Ughachukwu PO ${ }^{1}$, Ezenyeaku $\mathrm{CCT}^{2}$, Ochiogu $\mathrm{BC}^{3}$, Ezeagwuna $\mathrm{DA}^{4}$, \\ Anahalu I $\mathrm{C}^{4}$. \\ ${ }^{1 .}$ Department of Pharmacology and Therapeutics, College of Medicine, Anambra State University Awka \\ Campus, AnambraState, Nigeria. \\ 2. Department of Obstetrics and Gynecology, College of Medicine, Anambra State UniversityAwka Campus. \\ Anambra State, Nigeria. \\ 3. Department of Ophalmology, College of Medicine, Anambra State University Awka Campus, Anambra State, \\ Nigeria. \\ ${ }^{4}$ Department of Medical Microbiology, NnamdiAzikiwe University Teaching Hospital, NnewiAnambra State, \\ Nigeria.
}

\begin{abstract}
Preparations of the extract of Euphorbia heterophylla are used for the treatment of different infections by Nigerian traditional medicine practitioners. This work evaluated the antibacterial actions of aqueous leaf extract of Euphorbia heterophylla.Materials and methods: Clinical isolates of Klebsiellapneumonia, Staphyllococcusaureus, Escherichia coli, and Pseudomonas aeruginosa were incubated in agar plates after serial dilutions $(100,50,25,12.5,6.25$, and $3.16 \mathrm{mg} / \mathrm{ml})$ of the extract were added in wells made in the agar and incubated at $37^{\circ} \mathrm{C}$. After 24 hours, zones of inhibition (in mm) around the wells were measured. The same organisms were tested for sensitivity against standard antibiotics (ceftriaxone, ciprofloxacin, gentamicin, lincocin, and ofloxacin) using disk diffusion method. Microsoft Excel 2010 and Graph Pad Prism 6.0 were used for statistical analysis. Results: Phytochemical test showed that the extract contained saponins, tannins, alkaloids, resins, sterols and terpenoids. The extract demonstrated dose dependent antibacterial activity which was, however, apparently lower than that of the standard antibiotics. Conclusion: It was concluded that the extracthad significant antibacterial activity against test organisms with minimum inhibitory concentration (MIC) of $6.25 \mathrm{mg} / \mathrm{ml}$. Its use for treatment of infections by traditional healers is justified. Key words: Antibiotics, aqueous extract, bacteria, Euphorbia heterophylla, inhibition.
\end{abstract}

\section{Introduction}

Euphorbia heterophylla (E.heterophylla) is an annual weed. Alternative names of this weed include Euphorbia geniculate, Euphorbia pronifolia, Poinsettia geniculata and Poinsettia heterophylla ${ }^{[1]}$. It grows mainly in tropical and sub-tropical climates. In Nigeria, it is mainly found in cassava farms during the planting season.

In Igbo traditional medicine, the leaf extract is used as a purgative as well as for the treatment of gonorrheal, respiratory tract infection, malaria, and skin infection ${ }^{[1]}{ }^{[2]}$. It is commonly called nono-kunchiya in Hausa, egeleor aka- itoin Igbo and adimeru in Yoruba, Nigeria ${ }^{[2]}$.

Screenings of medicinal plants for antimicrobial activities are important for finding potential new compounds for therapeutic use.Medicinal plants readily provide sources of such novel agents. Herbs known to have antibacterial properties includeAcacia arabica, Nymphaea lotus, Sphareranthushirtus, Emblicaofficinalis, Cinchoriumintybus, Cardusmarianum, and Ficusexasperata ${ }^{[3],}{ }^{[4]}$.However, most of the antimicrobial studies on this plant were done using the ethanol extract. Even in traditional medical practice most of these plants are usually soaked in local gin to extract the active constituents. Knowing the toxic effect of alcohol on the liver, the aqueous extract will be safer. However, it is known that the extraction of the active constituents and therefore the efficacy of herbal remedy depend on the extracting solvent, geographical location, and soil characteristics among other factors ${ }^{[5]}$.

The aim of the study is to confirm the antibacterial activity of aqueous extract of E. heterophylla. Specific objectives of the study include:

(a) To determine the inhibitory effect of E. heterophylla on the growth of Klebsiella pneumonia (K.pneumonia),Staphyllococcusaureos (S.aureus), Escherichia coli (E.coli), andPseudomonas aeruginosa (Ps.aeruginosa).

(b) To compare the inhibitory effect of different concentrations of the extract on the growth ofK.pneumoniae, S.aureus, E.coli, andPs.aeruginosa.

(c) To compare the inhibitory effect of this extract and some standard antibiotics on the growth of K.pneumoniae, S.aureus, E.coli, and Ps.aeruginosa. 


\section{Materials And Methods}

This study was conducted at the Pharmacology and Medical Microbiology laboratories of NnamdiAzikiwe University, Nnewi Campus between February and July, 2012.

\subsection{Plant source}

Fresh leaves of E.heterophyllawere collected at Umuoji, Idemili North Local Government, Anambra State, Nigeria in the month of March 2012.The leaves were identified by Prof. C. U. Okeke ofBotany Department, NnamdiAzikiwe University, Awka.

\subsection{Preparation of aqueous extract}

Fresh leaves of E.heterophyllawere air-dried at room temperature.Thereafter, $200 \mathrm{gm}$ of the dry leaves were mashed in $250 \mathrm{mls}$ of water, filtered, and the filtrate evaporated to dryness using Soxhlet extracting apparatus.

\subsection{Phytochemical analysis}

Preliminary phytochemical test as described by Harbone (1973) showed that the extract contained saponins, tannins, alkaloids, resins, sterols and terpenoids ${ }^{[6]}$.

\subsection{Preparation of extract solutions}

Six (6) $\mathrm{g}$ of extract was dissolved in $60 \mathrm{ml}$ of water giving aconcentration of $100 \mathrm{mg} / \mathrm{ml}$. This was taken as stocksolution. Serial dilutions of the stock solution were prepared bymixing $1 \mathrm{ml}$ of stock solution with $1,2,3,4$ and $5 \mathrm{ml}$ of distilled watergiving $50,25,12.5,6.25$ and $3.16 \mathrm{mg} / \mathrm{ml}$ respectively.

\subsection{Laboratory procedures}

Isolates of S. aureus, E. coli, K. pneumomaeand P. aeruginosaused were obtained from NnamdiAzikiwe University TeachingHospital Clinics and stored in Oxford nutrient agar slants for one week before use. Twenty microliter nutrient agar was prepared according to the manufacturer's (Oxford) instructions. The agar was poured into six Petri dishes and allowed to set. The agar in Petri dishes were sterilized and allowed to cool. The plates were inoculated with test organisms. Seven equal holes $(6 \mathrm{~mm})$ were made in each agar plate with sterile cork borer (one of the holes being central in position); two plates each for E. coli, K.pneumomae S. aureusand P. aeruginosa. The Petri dishes were labeled with their respective organisms and the wells marked $100,50,25,12.5,6.25$ and $3.1 \mathrm{mg} / \mathrm{ml}$ respectively for easy identification. The wells were filled with 5 drops of corresponding dilution of the extract. The central well was filled with distilled water to act as the control. They were allowed to diffuse well into the agar medium and subsequently incubated at $37^{\circ} \mathrm{C}$ for 24 hours. Thereafter, the zones of inhibition produced by the different concentrations of the extract against the growth of the bacteria were measured and recorded. For comparison, the bacteria from the same clinical specimens were tested for sensitivity using standard antibiotic (ceftriaxone, ciprofloxacin, gentamicin, lincocin, and ofloxacin) diffusion discs.

\subsection{Statistical analysis}

Data generated from the measurement of zones of inhibition were subjected to analysis for analysis using Microsoft excel 2010. The data were further subjected to analysis for evidence of statistically significant differences in the zones of inhibition produced by the extract and those produced by some standard antibiotics. Results of the analyses were taken as statistically significant at $p$-value $\leq 0.05$.

\subsection{Aqueous extraction}

\section{Results}

Aqueous extractionof $200 \mathrm{gm}$ of the dry leaves of E. heterophyllayielded 11.5 gm extract (giving extractive value of $5.75 \%$ ).

\subsection{Phytochemical test}

Preliminary phytochemical test showed that the extract contained saponins, tannins, alkaloids, resins, sterols and terpenoids.

\subsection{Antibacterial activity}

The extract exhibited inhibitory effect on the growth of K.pneumoniae, S.aureus, E.coli, and Ps. aeruginosa as shown in Table 1 and Fig. 1. The extract also exhibited wide spectrum antibacterial activity against the said bacteria when compared to most of the orthodox antibiotics with which it was compared (ceftriaxone, ciprofloxacin, gentamicin, lincocin, andofloxacin) as shown in Table 2 and Fig. 2. However, these 
antibiotics produced higher zones of inhibition when compared with the extract (Table 2, Fig. 2, and Fig. 3). There was a statistically significant difference in the zones of inhibition produced by the extract against these bacteria, with S.aureus being the most susceptible (Fig. 4). There were also statistically significant differencesbetween the zones of inhibition produced by the standard antibiotics and those produced by the extract (Fig. 5).

Table 1: Inhibitory effect of increasing concentrations of ethanol leaf extract of E. heterophylla on the growth of

\begin{tabular}{|c|c|c|c|c|}
\hline Test organism & $\begin{array}{l}\text { Concentration of } \\
\text { extract }(\mathrm{mg} / \mathrm{ml})\end{array}$ & $\begin{array}{l}\text { Size of well in Size of } \\
\text { mm (A) of inhibition (B) }\end{array}$ & $\begin{array}{c}\text { I +area } \\
(\mathrm{B}-\mathrm{A})\end{array}$ & Zone of inhibition \\
\hline K. pneumonia & $\begin{array}{c}100 \\
50 \\
25 \\
12.5 \\
6.25 \\
3.16 \\
* \mathrm{C} \\
\text { Mean zone of inhi }\end{array}$ & $\begin{array}{r}6 \\
6 \\
6 \\
6 \\
6 \\
6 \\
6 \\
\text { tion }=\mathbf{2 . 0 0} \\
\end{array}$ & $\begin{array}{r}10 \\
9 \\
9 \\
8 \\
6 \\
6 \\
6\end{array}$ & $\begin{array}{l}4 \\
3 \\
3 \\
2 \\
0 \\
0 \\
0\end{array}$ \\
\hline S.aureus & $\begin{array}{c}100 \\
50 \\
25 \\
12.5 \\
6.25 \\
3.16 \\
* \mathrm{C} \\
\text { Mean zone of inhi }\end{array}$ & $\begin{array}{r}6 \\
6 \\
6 \\
6 \\
6 \\
6 \\
6 \\
\text { tion }=\mathbf{4 . 1 6} \\
\end{array}$ & $\begin{array}{l}11 \\
12 \\
11 \\
11 \\
10 \\
6 \\
6\end{array}$ & $\begin{array}{l}5 \\
6 \\
5 \\
5 \\
4 \\
0 \\
0\end{array}$ \\
\hline E. coli & $\begin{array}{c}100 \\
50 \\
25 \\
12.5 \\
6.25 \\
3.16 \\
* \mathrm{C} \\
\text { Mean zone of inhi }\end{array}$ & $\begin{array}{r}6 \\
6 \\
6 \\
6 \\
6 \\
6 \\
6 \\
\\
\\
\text { tion }=\mathbf{2 . 2 5} \\
\end{array}$ & $\begin{array}{l}10 \\
10 \\
9 \\
8.5 \\
6 \\
6 \\
6\end{array}$ & $\begin{array}{l}4 \\
4 \\
3 \\
2.5 \\
0 \\
0 \\
0\end{array}$ \\
\hline Ps. aeruginosa & $\begin{array}{c}100 \\
50 \\
25 \\
12.5 \\
6.25 \\
3.16 \\
* \mathrm{C} \\
\text { Mean zone of inhi }\end{array}$ & $\begin{array}{r}6 \\
6 \\
6 \\
6 \\
6 \\
6 \\
6 \\
\text { tion }=\mathbf{2 . 5 0} \\
\end{array}$ & $\begin{array}{l}9 \\
9 \\
10 \\
9 \\
8 \\
6 \\
6\end{array}$ & $\begin{array}{l}3 \\
3 \\
4 \\
3 \\
2 \\
0 \\
0\end{array}$ \\
\hline
\end{tabular}

$* \mathrm{C}=$ absolute alcohol. This was used to fill the central well to act as a control.

Table 2: Comparison of the effects of some orthodox antibiotics and ethanol leaf extract of E. heterophylla on the growth of different bacteria

\begin{tabular}{|c|c|c|c|c|}
\hline $\begin{array}{l}\text { Concentration of antibiotics } \\
\text { and extract }\end{array}$ & \multicolumn{4}{|c|}{ Bacteria and corresponding zones of inhibition (in $\mathrm{mm}$ ) } \\
\hline \multicolumn{5}{|c|}{ K.pneumoniaeS.aureusE.coliPs.aeruginosa } \\
\hline Ceftriaxone $(10 \mu \mathrm{g})$ & $8 \mathrm{~mm}$ & $11 \mathrm{~mm}$ & $27 \mathrm{~mm}$ & - \\
\hline Ciprofloxacin $(5 \mu \mathrm{g})$ & $5 \mathrm{~mm}$ & $2 \mathrm{~mm}$ & $25 \mathrm{~mm}$ & - \\
\hline Gentamicin $(10 \mu \mathrm{g})$ & $4 \mathrm{~mm}$ & $9 \mathrm{~mm}$ & $8 \mathrm{~mm}$ & $7 \mathrm{~mm}$ \\
\hline Lincocin $(10 \mu \mathrm{g})$ & - & - & $9 \mathrm{~mm}$ & - \\
\hline Ofloxacin $(5 \mu \mathrm{g})$ & - & - & $20 \mathrm{~mm}$ & $10 \mathrm{~mm}$ \\
\hline Extract $(100 \mathrm{mg} / \mathrm{ml})$ & $* 4 \mathrm{~mm}$ & $5 \mathrm{~mm}$ & $4 \mathrm{~mm}$ & $3 \mathrm{~mm}$ \\
\hline
\end{tabular}

*The growth inhibitions against the bacteria produced by the highest concentration of the extract $(100 \mathrm{mg} / \mathrm{ml})$. 


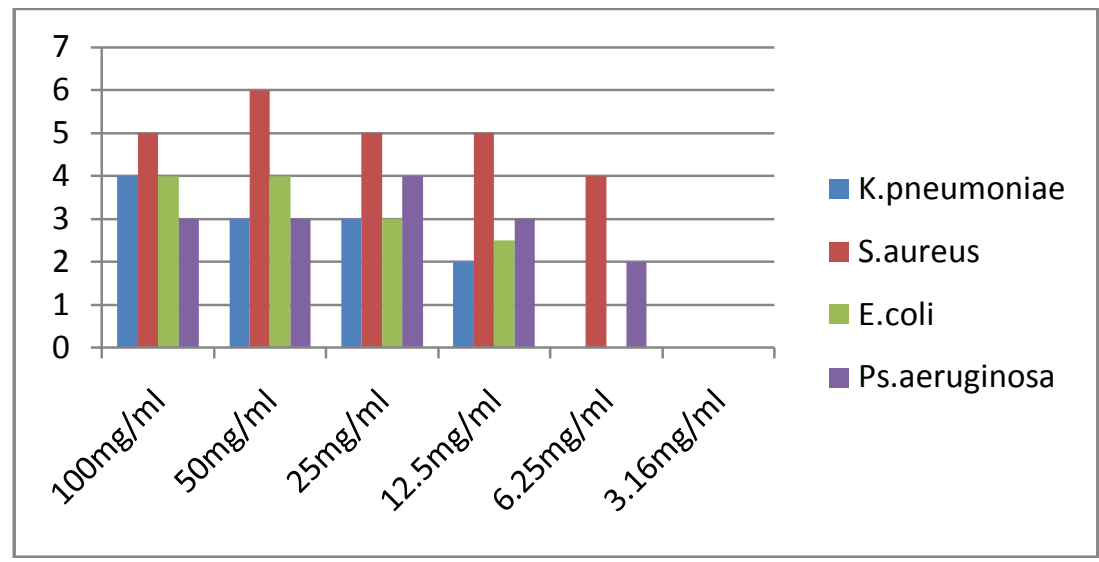

Figure 1: Bar chart showing dose dependent inhibition (in $\mathrm{mm}$ ) produced by aqueous leaf extract of E.heterophyllaagainst some bacteria.

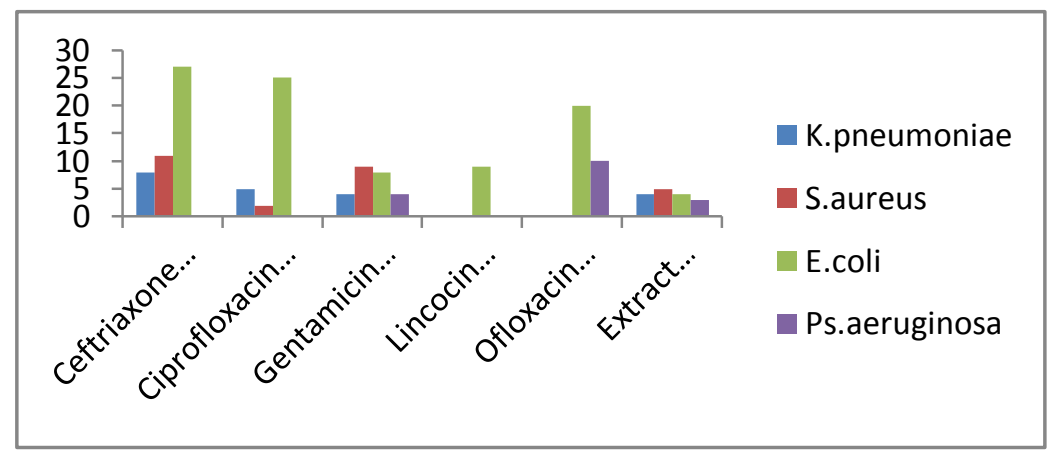

Figure 2:Bar chart comparing the zones of inhibition produced by some orthodox antibiotics and aqueous leafextract of E.heterophylla against the growth of some bacteria
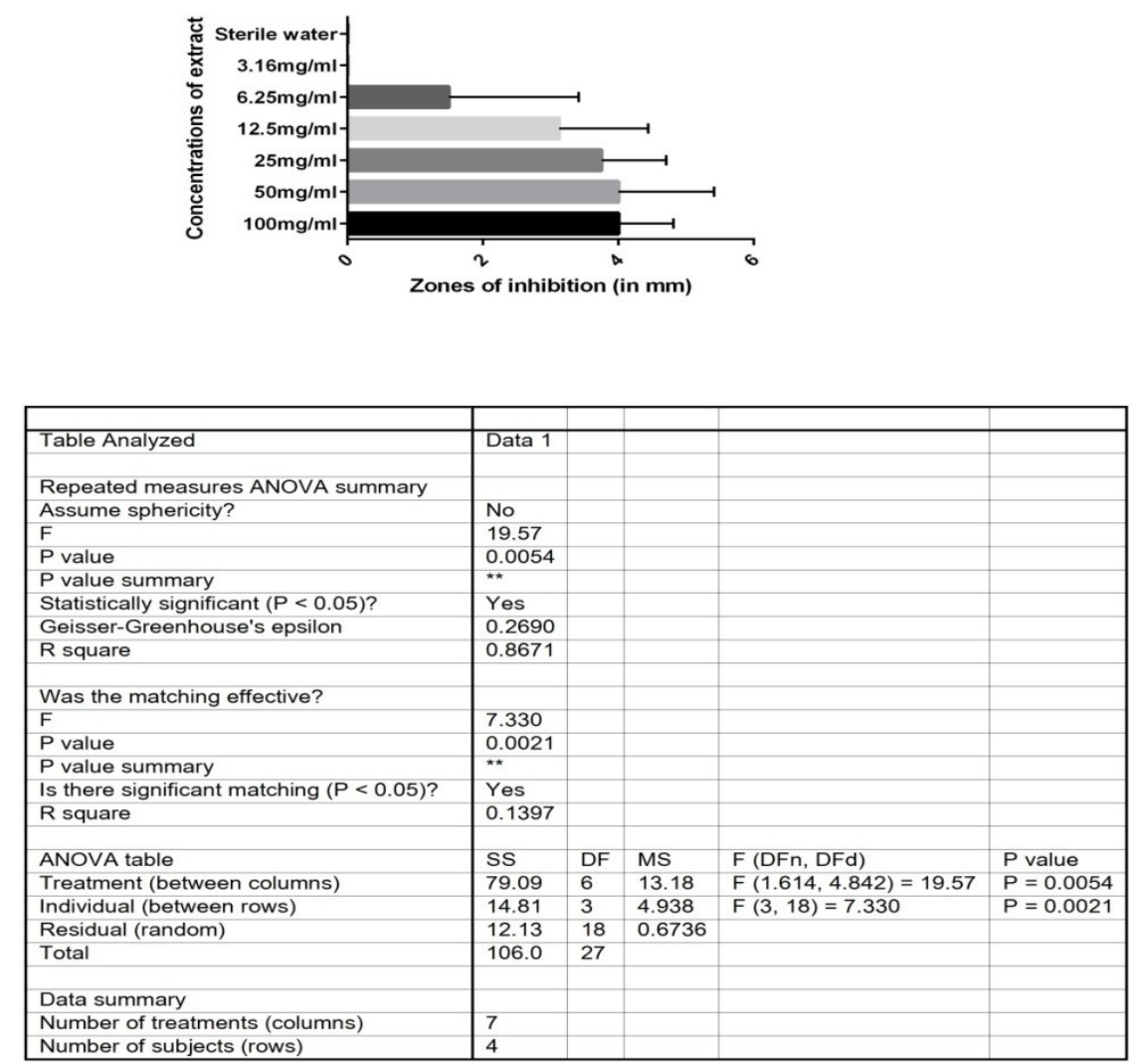

Figure 3: Analysis showing statistically significant differences in the zones of inhibition produced by different concentrations of aqueous leaf extract of E.heterophyllaagainst some bacteria. 


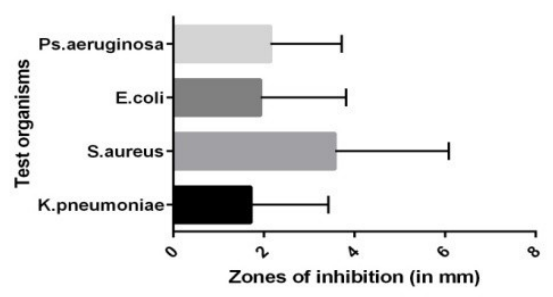

\begin{tabular}{|c|c|c|c|c|c|}
\hline Table Analyzed & Data 1 & & & & \\
\hline & & & & & \\
\hline \multicolumn{6}{|l|}{ Repeated measures ANOVA summary } \\
\hline Assume sphericity? & No & & & & \\
\hline $\mathrm{F}$ & 7.330 & & & & \\
\hline$P$ value & 0.0144 & & & & \\
\hline$P$ value summary & * & & & & \\
\hline Statistically significant $(P<0.05)$ ? & Yes & & & & \\
\hline Geisser-Greenhouse's epsilon & 0.5380 & & & & \\
\hline $\mathrm{R}$ square & 0.5499 & & & & \\
\hline \multicolumn{6}{|l|}{ Was the matching effective? } \\
\hline $\mathrm{F}$ & 19.57 & & & & \\
\hline$P$ value & $<0.0001$ & & & & \\
\hline$P$ value summary & $* \star \star \star *$ & & & & \\
\hline Is there significant matching $(P<0.05)$ ? & Yes & & & & \\
\hline $\mathrm{R}$ square & 0.7459 & & & & \\
\hline ANOVA table & ss & DF & MS & $F(D F n, D F d)$ & $P$ value \\
\hline Treatment (between columns) & 14.81 & 3 & 4.938 & $F(1.614,9.684)=7.330$ & $P=0.0144$ \\
\hline Individual (between rows) & 79.09 & 6 & 13.18 & $F(6,18)=19.57$ & $P<0.0001$ \\
\hline Residual (random) & 12.13 & 18 & 0.6736 & & \\
\hline Total & 106.0 & 27 & & & \\
\hline \multicolumn{6}{|l|}{ Data summary } \\
\hline Number of treatments (columns) & 4 & & & & \\
\hline Number of subjects (rows) & 7 & & & & \\
\hline
\end{tabular}

Figure 4: Analysis showing statistically significant differences in the zones of inhibition produced by aqueous leaf extract of E.heterophyllaagainst some bacteria.

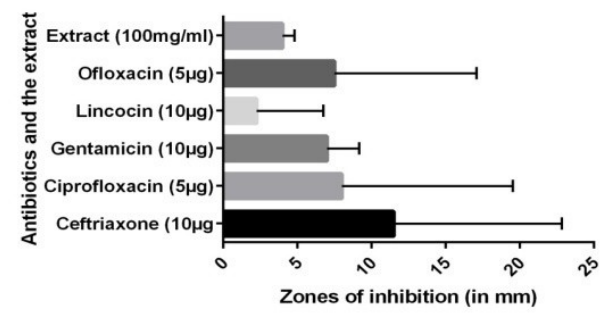

\begin{tabular}{|c|c|c|c|c|c|}
\hline Table Analyzed & Data 1 & & & & \\
\hline \multicolumn{6}{|l|}{ Repeated measures ANOVA summary } \\
\hline Assume sphericity? & No & & & & \\
\hline $\mathrm{F}$ & 1.233 & & & & \\
\hline$P$ value & 0.3555 & & & & \\
\hline$P$ value summary & ns & & & & \\
\hline Statistically significant $(P<0.05)$ ? & No & & & & \\
\hline Geisser-Greenhouse's epsilon & 0.3398 & & & & \\
\hline $\mathrm{R}$ square & 0.2912 & & & & \\
\hline \multicolumn{6}{|l|}{ Was the matching effective? } \\
\hline $\mathrm{F}$ & 6.090 & & & & \\
\hline$P$ value & 0.0064 & & & & \\
\hline$P$ value summary & 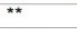 & & & & \\
\hline Is there significant matching $(P<0.05)$ ? & Yes & & & & \\
\hline $\mathrm{R}$ square & 0.4633 & & & & \\
\hline ANOVA table & ss & DF & MS & $F(D F n, D F d)$ & $P$ value \\
\hline Treatment (between columns) & 210.2 & 5 & 42.04 & $F(1.699,5.097)=1.233$ & $P=0.3555$ \\
\hline Individual (between rows) & 623.1 & 3 & 207.7 & $F(3,15)=6.090$ & $P=0.0064$ \\
\hline Residual (random) & 511.6 & 15 & 34.11 & & \\
\hline Total & 1345 & 23 & & & \\
\hline \multicolumn{6}{|l|}{ Data summary } \\
\hline Number of treatments (columns) & 6 & & & & \\
\hline Number of subjects (rows) & 4 & & & & \\
\hline
\end{tabular}

Figure 5: Analysis showing statistically significant differences in the zones of inhibition produced by some standard antibiotics and aqueous leaf extract of E.heterophylla against some bacteria. 


\section{Discussion}

As shown in in the results section, this extract exhibited a wide spectrum of antibacterial action against K.pneumoniae, S.aureus, E.coli, and Ps.aeruginosa. The inhibition of growth of the test organisms by the extract was dose dependent with the lowest effective concentration being $6.25 \mathrm{mg} / \mathrm{ml}$. This can be considered the minimum inhibitory concentration (MIC) of this extract against for S.aureus and Ps.aeruginosa. For K.pneumoniae and E.coli, the MIC was $12.5 \mathrm{mg} / \mathrm{ml}$. Odunbaku et al. had earlier found the MIC of this extract against E.coli to be $300 \mathrm{mg} / \mathrm{ml}^{[7]}$. This high MIC (low activity) could be due to differences in geographical location, season of plant, age of the plant, and method of extraction, all of which affect the yield and the active constituents of medicinal plants ${ }^{[8], ~}{ }^{[9]}$.It could also be due to differences in laboratory procedures and reagents used ${ }^{[10],}{ }^{[11]}$. The MICs observed in this study were also lower than those of another medicinal plant, Ficusexasperatawhose MIC was $100 \mathrm{mg} / \mathrm{ml}$ against K.pneumoniae and $25 \mathrm{mg} / \mathrm{ml}$ against E.coli, S.aureus, and Ps.aeruginosa ${ }^{[4]}$. Minimum inhibitory concentrations (the lowest concentration of drug which inhibits growth) are used by diagnostic laboratories to determine in vitro activity or resistance to both old and new antimicrobial agents $^{[12]}$.

The extract exhibited a wide spectrum of antibacterial activity when compared with most of the orthodox antibiotics tested as shown in Table 2 and Fig. 2. However, theseantibiotics produced higher zones of inhibition when compared with the extract (Table 2, Fig. 2, and Fig. 3).

Looking at the zones of inhibition produced by the extract and those produced by the standard antibiotics, one may be tempted to conclude that the latter are more efficacious in the treatment of infections caused by the above mention bacteria. However, it must be noted that the extract was used in its crude form, unrefined form. Therefore, the concentration of the active constituents in each given dose of the extract may actually be lower than those found in the orthodox antibiotics. Also, being crude, this extract could contain active constituents that interacted with one another thereby reducing its total inhibitory effect on the organisms. In fact, Kafaru et al. had earlier shown that purification of crude extract leads to loss of medicinal value ${ }^{[13]}$. On the other hand, Okoli and Iregbudemonstrated that the crude ethanolic extract of Synclisiascabridahad no antibacterial activity against clinical isolates of Proteus sp. which was susceptible to the purification product of the same plant ${ }^{[14]}$. The observed antibacterial actions of this extract could be attributed to the presence of saponins, tannins, and alkaloids which have proven antimicrobial properties ${ }^{[15],[16]}$.

It is interesting to note that S.aureus is Gram-positive while the rest are Gram-negative. Whereas K.pneumoniaeis an important cause of respiratory infection, E.coli causes gastroenteritis especially in children. E. coli, S. aureus, and Ps.aeruginosa are implicated in the aetiology of urinary tract infections, the latter two bacteria usually after instrumentation or in the immunocompromised ${ }^{[17]}$. It is important to note that the extract exhibited antibacterial activity against all bacterial species tested especially Ps.aeruginosa which is known to be resistant to many conventional antibiotics. Therefore, the use of the extracts of the leaves of this plant in the treatment of diarrhea, as well as urinary and respiratory infections in traditional medical practice appears justified.

\section{Conclusion}

The aqueous leaf extract of E.heterophyllaproduced dose dependent inhibitory effect on the growth of K.pneumoniae, S.aureus, E.coli, and Ps. aeruginosa, with S.aureus being the most susceptible. However, the standard antibiotics produced higher zones of inhibition when compared with the extract. Therefore the use of extracts of this plant in the treatment of respiratory, urinary tract, and gastrointestinal infections in traditional medical practice is justified. Clinical trials using refined products of this extract are strongly recommended especially as this extract exhibited broad spectrum antibacterial action against the organisms tested. This plant being readily available in commercial quantity in most tropical regions will provide alternative and cheap sources of antimicrobial agents. Also, because the extract has not been abused, drug resistance to it will not be a problem.

\section{References}

[1]. P.C. Unekwe, P.O. Ughachukwu, and J.O. Ogamba, Some pharmacological studies of aqueous extract of leaves of Euphorbia heterophylla. Tropical Journal of Medical Research, 10(2), 2006, 1-5.

[2]. S.O. Okeniyi, B.J. Adedoyin, and S. Garba, Phytochemical screening, cytotoxicity, antioxidant, and antimicrobial activities of stem and leave extracts of Euphorbia heterophylla, Bull Environ PharmacolLife Sci, 1(8), 2012, 87-91.

[3]. A. Hassan,S. Rahman, F. Deeba, andS. Mahmud, Antimicrobial activity of some plants extracts havinghepatoprotective effects. JMPR, 3(1), 2009, 20-23.

[4]. P.O. Ughachukwu,C.C.T. Ezenyeaku, D.A. Ezeagwuna, and I.C. Anahalu, Evaluation of antibacterial properties of ethanol extract of Ficusexasperata leaf. AJB, 11(16), 2012, 3874-3876.

[5]. A.K. Dutta, P.S. Gope, S. Makhnoon, M.S. Rahman, M.A. Siddiquee, and Y. Rabir, Effect of solvent extraction on phenolic content, antioxidant, and $\alpha$-amylase inhibition activities of Swertiachirata. Int J Drug Dev\& Res, 4(4), 2012, $317-325$.

[6]. J.B. Harbone,A guide to modern techniques of plant analysis. London, Chapman and Hall, 1973.

[7]. O.A. Odunbaku, O.A. Ilusanya, and K.S. Akasoro, Antibacterial activity of ethanolic leaf extract of Ficusexasperata on Escherichia coli and Staphylococcus albus. Sci Res Essays, 3(11), 2008, 562-564. 
[8]. J.B. Calixto, Efficacy, safety, quality control, marketing andregulatory guidelines for herbal medicines. Braz J Med Biol Res, 33, 2000, 179-189.

[9]. W.C. Evans, Trease and Evans Pharmacognosy. London, WB Saunders, 2002.

[10]. P. Bonini, M. Plebani, F. Cerrioti, and F. Rubboli, Errors in laboratory medicine. ClinChem, 48, 2002, 691-698.

[11]. J.B. Wallack,Interpretation of diagnostic tests. Philadelphia. Lippincott Williams \& Wilkins, 2007.

[12]. J.M. Andrews, Determination of minimum inhibitoryconcentrations. J AntimicrobChemother, 4 (6), 2002, 1049.

[13]. C.J. Kafaru, M.B. Keay, and C.F. Roper, Flavonoids: antibacterial constituents ofVitexdoniana. J Nat Sci, 6, 1994, 80-81

[14]. S. Okoli, and C.U. Iroegbu, In vitro antibacterial activity of Synclisiascabrida whole root extracts. AJB 4(9), 2005, 946-952.

[15]. E. Omulokoli, B. Khan, and S.C. Chabra,Antiplasmodial activity of four Kenyan medicinal plants. J Ethnopharmacol, 56, 1997, $133-137$.

[16]. B. Nandi, S. Roy, S. Bhattacharya, and S.P. Babu, Free radicals mediated membrane damage by the saponinsacaciaside A and acaciaside B. Phyther Res 18(3), 2004, 191-194.

[17]. J.M. Willy, L.M. Sherwood, andC.J. Woolveerton, Prescott, Harley, and Klein's Microbiology. New York. McGraw-Hill Companies Inc, 2008. 